\title{
Editorial: Chaos in South Asia
}

\author{
Anthony Marcus • Ananthakrishnan Aiyer • \\ Kirk Dombrowski
}

Published online: 20 October 2009

(C) Springer Science+Business Media B.V. 2009

After a brief respite in the last issue in the form of an editorial by James Petras on academics who build their research around helping to manage imperialist violence, we return to the theme of our last editorial-and perhaps some of the previous ones-chaos. It is difficult not to spend a lot of time thinking about this theme in the "complex age" in which we live. In this special issue, we turn to South Asia, a place that by all accounts is especially "complex." Despite being home to what may be the largest agrarian population and most militant working class in the world, this region has been entirely neglected by Dialectical Anthropology for almost half a decade. We hope to change that with this special issue on Maoism and insurgency in Nepal and India's "red corridor"-some 92,000 square kilometers from the Nepalese border to Tamil Nadu. We hope that this will be the beginning of a longterm project to recenter South Asia's large, young, and often angry peasantry and rural/urban working class in the discussions and debates that drive our publication.

As mentioned earlier, the most common word that we have heard when raising the question of South Asian sociopolitical life is "complex." As far as we can tell from a cursory survey a more accurate description would be "mess." It seems that chaos reigns. How could it be otherwise after centuries of imperial rape followed by decades of neo-colonial combined and uneven capitalist development? Nepal, which figures in half of the articles we present is one of the poorest countries in the world. As most readers will know, it is a mountainous country attached to northern India by geography, politico-historic ties, and a shared religion. It continues to exist in an uneasy civil unrest torn by a Maoist insurgency, a revanchist monarchy, and a capitalist "civil society" that remains too poor and weak to help the other two elements bring Nepal into the "international community," even though international globetrotters hoping to scale Mt. Everest visit here in large numbers and leave ever larger hillocks of cans and styrofoam on the mountain trails. Perhaps, the key

A. Marcus $(\bowtie) \cdot$ A. Aiyer · K. Dombrowski

University of Melbourne, Parkville, Victoria, Australia

e-mail: amarcus@unimelb.edu.au 
nationalist myth promoted by all sides of the conflict is that Nepal is special for never having suffered the colonial exploitation that has defined the history of so many other third world peoples. A cursory look at Nepalese sociopolitical development suggests that this may prove the old adage that the only thing worse than being exploited is not being exploited.

Then, there is India. If the amount of wealth stolen during colonialism is an indicator of how exploited a people are and have been, we could probably rank India the most exploited country on earth. Such a perspective has been derided by a new generation of post-colonial pundits in the Foucauldian mind-over-matter tradition of Arturo Escobar, who are tired of people in the First world turning people in the Third world into what Nanda Shrestha has termed a "development category" by pathologizing their culture. Well India may be "the world's largest democracy", producing the world's cheapest cars and space capsules, for "the world's largest middle class" (although reasonable economists doubt that), but that middle class sits astride the world's largest number of people, especially rural denizens, living on less than $\$ 1.25$ a day; all the while, a tiny bourgeoisie shares the house of their former English masters. And while the Tatas are busy planning to lay off some employees from their new takeover of Jaguar and "Slumdog Millionaire" kids are paraded in cities, peasants and even some well-to-do-farmers around the country are busy committing suicides as the Indian state continues to turn its back on villages and rural towns. We might also note that India has the most inter-communal conflicts of any country in the world and, by some accounts, the most social scientists, the largest number of software engineers, and the second largest Muslim population. As the world's second most populous country, superlatives should be no surprise, but they all add up to the most chaos and degradation for the most number of people, to take a page from the old utilitarian formula.

Turning west, south central (Asia that is) is burning. Pakistan is in the midst of a war that is so stupid and needlessly chaotic that we are at a loss to even characterize it. The Pakistani army has now displaced over 1.5 million people in its north, because of a campaign promise, by Barack Obama (that was too bellicose even for his opponent, McCain), to bomb Pakistan if they don't do it to themselves first. Judging from the peace treaty that the Pakistani government signed with so-called Taliban leaders to the north, just days before the barrage, we can only assume that Islamabad is just as non-plussed as the editors of Dialectical Anthropology about why they are being forced to bomb their own people. As far as we can tell, the Taliban, whoever they really are, have had influence, if not governance powers in the regions north of Islamabad for a long time. This right-wing agrarian populist/ Islamicist warlord power might even go back to the days when the United States was trying to destabilize the southern tier of the Soviet Union and stop the spread of national health care and female literacy to Afghanistan. With little in the way of outside support, no escape route from the Swat Valley, and no air power, we can only guess that the Pakistani government has decided that the possibility of a rare military victory for its army might balance off a refugee crisis of large proportions.

As for the continuing question of the brutal oppression of women, even if you include the great connurbations of Pakistan's industrial heartland, where notions of modern progress are important and female professors teach at coeducational 
universities, female literacy is an abysmal $35 \%$ nationally-roughly half male rates. So, what is it really that the Taliban represent in the North, except another version of the patronage, corruption, and political devolution that is rural Pakistan. And why is everybody so worried about saving Muslim women all of a sudden?

An almost textbook case of combined and uneven capitalist development, all of rural Pakistan is run by lords; most get their authority from birth into landholding families, some get their authority from charisma, and others from war and the military-which seems to be the only stable (yet corrupt) institution in most of rural Pakistan-but we doubt that any of these traditional and neo-traditionalist rulers allow any room for women to go off the program of grinding rural poverty and obedience to the ritual abuses of local patriarchy. We would guess that the patriarchy of neo-feudal lords $40 \mathrm{~km}$ from Lahore produces similar outcomes to the loony agrarian/Islamicist warlord populism of the Taliban further north-especially if the dramatically lesser economic resources of the north are considered.

The Pakistani bourgeoisie has never been able to take much honey from the north, so they have let the bees do what they like there. These "Taliban" are warlords who rule locally. They have about as much chance of taking the glass and steel skyscrapers and nuclear laboratories of the Punjabi heartland as indigenous Zapatista had of managing the Mexico City subway system. At least the Zapatistas played to a national audience. The Taliban have showed little interest in the condition of the vast Pakistani working classes of Karachi, Lahore, and the industrial cities of the south. Similarly, those angry simmering working classes have shown little interest in the Taliban, until now, perhaps; now that they are symbols of opposition to an Uncle Sam imposed internal war.

As for Afghanistan, the lack of leadership by Humvee hood ornament Ahmed Karzai, affectionately also known as the "Mayor of Kabul," is even starting to disgust the White House, which seems to have finally decided that it has spent enough time meting out chaos and death to Pakistan and is ready to move its gun sights to Afghanistan again. However, what also remains the case is that Afghanistan remains firmly a part of the newer sitcom version of "The Great Game," as the U.S. and its NATO allies seek to create an Eastern bulwark that could potentially keep a phantasmagoric "Chinese threat" in check.

Turning to more cheerful locales, there is Bangladesh, one of the most densely populated countries in the world. Sitting on a flood prone land that may soon be under water thanks to anthropogenic climate change; if the flooding doesn't get you, the poverty will. Roughly half the population lives on less than $\$ 1.25$ a day, rivaling Nepal, military intervention in political life is taken as nearly a given to "keep the peace", and the only good thing that one can say about social development outcomes is that HIV seroprevalence rates remain low and the dismal $40 \%$ female literacy is balanced off by the fact that the male literacy rate is only slightly above $50 \%$, meaning that men and women are close to equal in their structural ignorance. In a script that would have even made Ionescu blush, we have the peculiar situation of the Nobel Peace Prize being awarded to a banker. His claim to fame: how to turn millions of starving and poor Bangladeshis from being cash-strapped to cashstrapped and deeply in debt. While no serious shift has taken place in these microentrepreneurs picking themselves out of poverty, it has certainly made the Grameen 
Bank spin-off enterprises, like cell phones (in a country where $60 \%$ do not have access to electricity), millions of dollars in profits. If self-subjugating neo-liberal subjects can be created in a country where even pre-neo-liberal capitalism remains tenuous, it is no wonder that the Gates' and Soros, along with a host of NGOs, have rushed to take up this new form of "development". And, now, with the help Mexico's Carlos Slim, reputed to be the third wealthiest man in the world, the magic of microfinance is coming to Mexico. Got you, Zapatistas! How do you organize against "compassionate lending"?

Perhaps, the only two peaceful places are The Republic of Maldives and Bhutan. The latter is a mountain kingdom of 600,000 people that nobody knows anything about, but Business Week magazine has described as the "seventh happiest country on earth." This should set off everybody's bullshit detector. This, especially given the fact that the country is largely a theocracy and that it has been particularly brutal to its own "ethnic minorities" (many of whom were desperate enough to migrate to Nepal) and to the many undocumented Nepalese who live and work in Bhutan. Then, there is the Republic of Maldives, the region's success story. It is an atoll based $100 \%$ Muslim archipelago nation in the middle of the Indian Ocean. It boasts rising incomes, rising standards of living, high, but still rising literacy rates for men and women, and the rise of multi-party governance. The Maldives might be the only place in the region that could claim it is developing peacefully and efficiently. This is due to a tourist boom driven by a resource frontier extraction economy. The central government is converting natural resources, in the form of islands, into accumulation in the form of tourist resorts, furiously trying to raise cash in expectation that the entire country will be under water soon, thanks to sea levels rising by virtue of the mismanagement of the environment by the world bourgeoisie. Many people believe that the country only has 50-100 years left and the feeling on the part of the last generations of this 1,500-year-old settlement, which boasts the highest divorce rate in the world, is, to take a line from Jim Morrison, "get your kicks before the whole shit-house goes up in flames." Maybe the best capitalist is one who is not hampered by the expectation of living a long time.

But we have saved the best for last. When it comes to chaos and sheer chutzpah, there is no bourgeoisie that can match the Sinhalese Buddhists of Sri Lanka. With the international community as its enabler, it has recently defeated the national liberation struggle in "Tamil Eelam" (the far northern coastal strip inhabited by Hindu and Christian Sri Lankan Tamils) in one of the most shocking examples of ethnocidal violence that we have seen in years. You do not have to be a Marxist, a third world liberation fighter, or even functionally literate to realize that this imperialist system puts a very low price on the lives of "brown people". So what is really so shocking about Sri Lanka, where the 60-80 thousand who have died really don't compare much to, for instance ethnocide in Africa, tidal waves in Asia, or the original sin of kidnapping 10 of the first 12 million people to travel to the New World. What we find genuinely shocking is the way that the international community has cheered on the ethnocide, allowing the Sri Lankan state to pose this as an issue of fighting terrorism, rather than as an issue of self-determination. It is the double standard of power. Or as Chomsky observed so many years ago, the emperor and the pirate do the same thing, but the pirate is in the wrong. 
And this is the reason we find the destruction of the LTTE by the Sinhalese army so shocking: the issues of commensurability, scale, and basic bourgeois legal notions of justice and fairness. Putting aside the stated goal of this journal, "to transform class societies", for a few minutes, we would just like to see a little old fashioned rational logic applied. To draw a loaded comparison, let's look at Israel. The whole world was appropriately up-in-arms at the incommensurate response of the Zionist state in the pre-election Gaza war. There is no way that anybody with any sense of justice can accept a nuclear armed imperial monster turning a defenseless and largely civilian city into wreckage to save face (which sadly brings us back to September 11, 2001, Afghanistan, and south central Asia burning). However, at least when the Israeli state makes thousands in Gaza homeless and orphaned, they can claim, albeit with some disingenuousness, that they are defending a piece of land that is being claimed equally by another group of people. Instead of admitting to the imperial nature of a theocratic Jewish state, they can say, "two antagonistic peoples, one land, its them or us." If they were genuinely fighting for the life of their people, rather than governing an imperial project by dividing Hebrew and Arabic speaking working classes, they might actually have a point, but at least they have a seemingly rational argument for why they deal out death to ordinary people because of their nationality. What is the Sri Lankan state's excuse for waging a quarter century war to prevent self-rule in a tiny strip of Northern coastal land claimed as a Tamil home? And why does the "international community" agree that incinerating civilians to shore up the central government's tenuous claims is commensurate. It may be too busy saving Muslim women further north from their menfolk to do the math.

Granted the northern Tamils have been represented by a rather repulsive outfit called the LTTE, but this is a political leadership so secretive, so repressive and so undemocratic that it could only emerge from a situation of the most brutal majoritarian repression. Described as terrorists, despite years of relatively successful autonomous self-management, including tax collecting, legal conflict resolution, maintenance of civilian and military armed forces, education, and even public libraries, the LTTE has often shown better governance practices than the official government to the south. While the years of anti-Tamil concentration camps and ethnic butchery have been ugly, we have watched in particular horror during the final offensive of 2009, when the Sri Lankan airforce took advantage of the destruction of the "Air Tigers" (the collection of aging propeller planes that the LTTE called their air force) to use modern aircraft to bomb civilians and combatant alike. Even the Kurds have received better consideration-perhaps thanks, in part, to anti-Turkish Europeans and a congeries of Greek and Armenian oriented politicos in the United States.

This is not two people's claiming the same land, as would be the case if the Tarahumara tried to take Arizona. This is one people seeking to liberate their tiny homeland in the north of Sri Lanka from a hostile majority government that seeks to fold them into a greater Sinhalese Buddhist Sri Lanka. If you do not believe this, take a look at the President of Sri Lanka's victory statement. In it, he made no pretense to a civil or secular character to the struggle. He boldly informed the world that the coming peace would be governed by Buddhist principles. Now, for many, 
this might mean peace, love, Richard Gere, and the Dalai Lama, but for the predominantly Hindu and Christian Tamils, it means no justice, no peace, and no self-determination. And just to put things in perspective, the president is a conciliator who has agreed to bring northern Tamil leadership into the government in limited ways. This stands in bold contrast to the groups of Buddhist priests who are calling for the blood of the Hindu and Christian losers of this war.

If this country, that continues to confine hundreds of thousands in what amount to concentration camps, is at peace than we think that there is no greater example, in South Asia, of the inability of the global bourgeoisie to properly manage this planet. We find more optimism in the situations in Nepal, and India, where peace still remains somewhat elusive. At least these conflicts seem to be subject to some notion of commensurability by an international community that is too concerned about losing control of a significant section of food producers and the world working class and the value they produce to completely discard the idea of commensurabililty. 